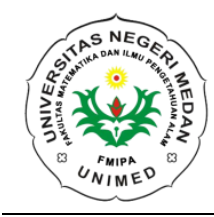

\author{
JURNAL EINSTEIN \\ Jurnal Hasil Penelitian Bindang Fisika \\ Available online http://jurnal.unimed.ac.id/2012/index.php/einsten \\ e-issn: $2407-747 x$, p-issn $2338-1981$
}

\title{
RANCANG BAGUN ALAT PENDETEKSI KELAYAKAN AIR MINUM YANG DIPRODUKSI DEPOT AIR MINUM ISI ULANG (AMIU) BERBASIS MIKROKONTROLER AT89S51 DAN LCD MENGGUNAKAN INFRAMERAH DAN PHOTODIODA SEBAGAI INDIKATOR
}

\author{
Irpan Afandi, Khairul Amdani \\ Jurusan Fisika, Fakultas Matematika dan Ilmu Pengetahuan Alam, Universitas Negeri Medan, \\ Indonesia \\ irpanafandi41@yahoo.com \\ Diterima April 2018; Disetujui Mei 2018; Dipublikasikan Juni 2018
}

\begin{abstract}
ABSTRAK
Penelitian ini bertujuan untuk mengetahui kelyakan air minum isi ulang yang diproduksi depot air minum dengan menggunakan mikrokontroler AT89S51 yang difungsikan sebagai penghitung kadar zat terlarut serta derajat keasaman $(\mathrm{pH})$. Prinsip dari alat ini adalah menampilkan menampilkan kadar zat terlarut serta derajat keasaman pada air minum di LCD. Rangkaian sensor menggunakan photodioda, yang dirangkai sehingga dapat mendeteksi sumber cahaya yang mengenai penampang photodioda ke bentuk energi listrik yang mampu direspon oleh mikrokontroler. Sumber cahaya sebagai receiver menggunakan sinar inframerah yang mengeluarkan cahaya fokus. Rangkaian penampil menggunakan LCD yang menampilkan nilai kadar zat terlarut serta derajat keasaman air minum dengan menggunakan sensor $\mathrm{pH}$. Dari hasil pengujian yang telah dilakukan, alat ini mampu mendeteksi dan menampilkan jumlah kadar zat terlarut dengan rentang 15-240 ppm. Berdasarkan data pengukuran pada tabel 4.3 selisih nilai koefisien yang diperoleh pada kadar zat terlarut (TDS) air minum isi ulang yang diproduksi depot air minum sebesar 0,002 sedangkan nilai koefisien derajat keasaman $(\mathrm{pH})$ air minum sebesar 0,474 . Berdasarkan hal di atas, maka alat pengukuran yang dirancang pengukuran kadar zat terlarut (TDS) dan derajat keasamman $(\mathrm{pH})$ dengan menggunakan inframerah dan photodioda serta sensor $\mathrm{pH}$ dapat difungsikan seperti alat ukur pada umummnya.
\end{abstract}

Kata Kunci : Inframerah,photodioda, sensor pH, mikrokontoler, assembly.

\section{PENDAHULUAN}

Air merupakan sumber kehidupan, tidak hanya manusia makhluk hidup lainnya juga membutuhkan air. Air sebagai komponen lingkungan hidup yang akan mempengaruhi dan dipengaruhi oleh komponen lainnya. Air yang kualitasnya buruk akan mengakibatkan lingkungan hidup menjadi buruk sehingga akan mempengaruhi kesehatan dan keselamatan manusia. Air adalah sumber kehidupan yang paling penting bagi kehidupan manusia, air bersih sangat dibutuhkan dan dimanfaatkan oleh manusia untuk dikonsumsi seperti keperluan minum, masak makanan atau melakukan aktivitas sehari-hari.

Dalam hal memenuhi kebutuhan minuman, kebutuhan masyarakat akan air minum bersih dan sehat semakin meningkat. Pada saat sekarang sudah banyak sekali usahausaha kecil yang mempermudah kebutuhan 
Irpan Affandi dan Khairul Amdani, Rancang Bagun Alat Pendeteksi Kelayakan Air Minum Yang Diproduksi Depot Air Minum Isi Ulang (Amiu) Berbasis Mikrokontroler At89s51 Dan Lcd Menggunakan Inframerah Dan Photodioda Sebagai Indikator

orang dalam memenuhi kebutuhan air minum konsumen seperti depot-depot air minum isi ulang. Dengan adanya depot air isi ulang ini, mempermudah masyarakat agar tidak membuang-buang waktu untuk menyiapkan air minum yang diperlukan setiap harinya karena cukup memesan air isi ulang tanpa perlu memasak air terlebih dahulu.

Masyarakat mulai beralih pada air minum isi ulang yang diproduksi depot pengisian air. Air minum ini lebih dikenal dengan air minum isi ulang karena masyarakat memperoleh air minum ini dengan cara mengisi galon yang dibawanya ke depot air minum. Dilihat dari harganya, air minum isi ulang jauh lebih murah yaitu hanya sepertiga dari harga air minum dalam kemasan. Hal inilah yang menyebabkan air minum isi ulang bermunculan. Keberadaan depot air minum isi ulang terus meningkat sejalan dengan dinamika keperluan masyarakat terhadap air minum yang bermutu dan aman untuk dikonsumsi. Meski lebih murah, tidak semua depot air minum isi ulang terjamin keamanan produknya.

Pengukuran dalam fisika adalah kegiatan menggunakan alat-alat ukur dengan tujuan mengetahui nilai suatu besaran. Pengukuran nilai kadar zat terlarut (TDS) pada air minum adalah tes dari kualitas air minum ataupun kelayakan air minum untuk dikonsumsi. Untuk mengetahui tingkat kadar zat terlalur (TDS) pada air minum dapat digunakan alat ukur TDS meter sedangkan untuk derajat keasaman digunakan $\mathrm{pH}$ meter. TDS meter adalah alat untuk mengukur partikel padatan terlarut di air minum yang tidak nampak oleh mata. Pengukuran ini menggunakan metode Electrical conductivity, dimana dua probe dihubungkan ke larutan yang akan diukur, kemudian dengan rangkaian pemprosesan sinyal mengeluarkan output yang menunjukan besar konduktifitas larutan tersebut, yang jika di kalikan dengan faktor konversi maka akan didapatkan nilai kualitas air tersebut dalam TDS (Total Dissolved Solid) atau PPM (Part Per Million).

Dalam penelitihan (Aryanto,dkk. 2010) yang mengidentifikasi kelayakan Air Minum Dalam Kemasan (AMDK) menggunakan inframerah (tx) dan photodioda ( $\mathrm{rx}$ ) yang di kuatkan dengan op-amp dan diolah menjadi satuan ppm. Pada pengujian air minum dalam kemasan, air minum terlebih dahulu diproses dengan elektrolisa yaitu proses yang memunculkan partikel-partikel dalam air dan selanjutnya diukur kadar zat terlarut (TDS) dalam air minum tersebut. Tingkat kekeruhan air sebanding dengan ppm. Dari Pengujian diketahui bahwa air minum dalam kemasan yang beredar dipasaran kebanyakan tidak memenuhi standar kelayakan air minum yang ditetapkan oleh WHO. Dimana air minum dalam kemasaan mempunyai kadar zat terlarut lebih dari 100 ppm. Pada uji coba tersebut kelayakan Air Minum Dalam Kemasan menunjukan tingkat keakurasian alat sekitar 88,605\%. Eror yang terjadi disebabkan oleh eror pada penguat serta pembacaan photodioda.

Pada penelitihan (Yefri, 2012) merncang alat ukur tingkat kekeruhan zat cair berbasis mikrokontroler AT89S51 dengan menggunakan sistem sensor yang terdiri dari LED dan fototransistor, serta tampilan LCD. Alat ukur ini bekerja berdasarkan prinsip hamburan cahaya oleh partikel-partikel tersuspensi di dalam zat cair, dengan posisi fototransistor adalah 90o terhadap cahaya yang datang dari LED (disebut metode Nephelometer). Kesalahan relatif ratarata alat ukur tingkat kekeruhan zat cair hasil rancang bangun ini adalah 3,03\% dan kesalahan relatif maksimumnya adalah sebesar $12,5 \%$.

Pada penelitihan (Nazula dan Endarko, 2013) merancang alat ukur kekeruhan air berbasis mikrokontrolel ATMega 8535 yang menggunakan sensor photodioda untuk mengukur tingkat kekeruhan air. Pada alat ukur kekeruhan bekerja berdasarkan metode Nephelometer yaitu hamburan cahaya oleh partikel - partikel tersuspensi didalam zat cair. Jarak antar LED dan detektor fotodioda pada alat ini adalah 2 inci yang diletakkan dalam posisi sejajar satu sama lain. Alat ini mampu mengukur tingkat kekeruhan air pada rentang 0 - 200 NTU serta mempunyai standar deviasi maksimum sebesar 1,33 NTU.

Pada penelitihan (Filemon, 2013) merancang alat ukur kekeruhan air menggunakan sensor LDR (Light Dependent Resistor), dimana sensor ini dapat mendeteksi 
cahaya dari tingkat cahaya Dioda LED (Light Emitting Diode) yang menembus air tersebut, maka akan terdeteksi kekeruhan air. Dalam sistem ini yang menjadi pengendali adalah mikrokontroler ATMega 8535. Keluaran dari alat ini adalah tingkat persentase kekeruhan air yang akan ditampilakan di LCD (Liquid Crystal Display).

Alat pendekteksi air minum isi ulang ini akan menggunakan sinar inframerah sebagai transmitter dan photodioda sebagai receiver yang di kuatkan dengan op-amp yang akan diolah menjadi satuan ppm yang pendekteksiannya dilakukan sudah melewati proses elektrolisa. Photodioda digunakan untuk mendeteksi kadar zat yang terlarut (TDS) dalam air minum, yaitu dengan cara melewatkan air diantara receiver dan transmitter. Tegangan pada photodioda sangat tergantung pada intensitas cahaya yang mengenai permukaan photodioda. Intensitas cahaya yang diterima photodioda akan dikonversi menjadi sinyal tegangan. Nilai tegangan kadar zat terlalur (TDS) air minum ini sebanding dengan nilai tegangan kekeruhan air.

Pengukuran $\mathrm{pH}$ air minum digunakan sensor $\mathrm{pH}$, prinsip kerja utama pada sensor $\mathrm{pH}$ adalah terletak pada sensor probe berupa elektroda yang berkerja untuk $\mathrm{pH}$ dan elektroda refrensi. Perbedaan potensial antara 2 elektroda sebagai fungsi $\mathrm{pH}$ larutan yang diukur. Pada elektroda $\mathrm{pH}$, potensial yang dihasilkan (biasanya dalam $\mathrm{mV}$ ) adalah berbanding lurus dengan konsentrasi ion hydrogen $\left(\mathrm{H}^{+}\right)$dalam larutan. Sedangkan, elektroda referensi berguna untuk mempertahankan potensial secara konstan terlepas dari adanya perubahan $\mathrm{pH}$ atau aktivitas ionik lainnya dalam larutan.

\section{METODE PENLITIAN}

\section{Tempat dan Waktu Penelitian}

Pelaksanaan penelitian, meliputi perakitan dan pengujian akan dilaksanakan di Laboratorium Fisika FMIPA Universitas Negeri Medan selama 2 bulan.

\section{Alat Dan Bahan}

Alat

Mikrokontrolel AT 89S51, Inframerah, Photodioda, Sensor pH, Laptop, Catu daya, LCD 2x16, ADC 0809

\section{Bahan}

Resistor, Potensiometer, Saklar, Transistor, Switch reset'

\section{Rancangan Sistem}

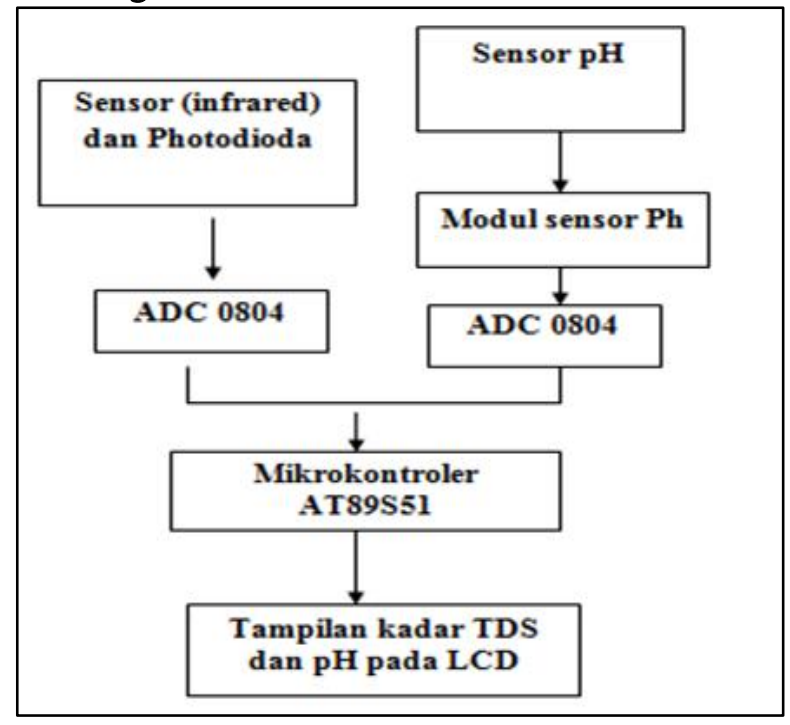

Analisi Data

Langkah-langkah dalam menganalisa data, yaitu:

1. Pengujian pertama akan menguji kadar zat terlarut pada air minum melalui intensitas cahaya yang mengenai photodioda.

2. Pengujian kedua akan menguji derajat keasaman air minum dengan sensor $\mathrm{pH}$.

3. Data yang telah diperoleh dari hasil tampilan LCD dan data yang diperoleh dari hasil pengukuran menggunakan TDS meter dan $\mathrm{pH}$ meter dibandingkan.

\section{HASIL DAN PEMBAHASAN}

\section{Hasil Penelitian}

Sistem alat ini terdiri dari perangkat keras yang merupakan alat pendeteksi kadar zat terlarut (TDS) dalam air minum yang berbasiskan mikrokontroler AT89S51, inframerah, photodioda,sensor $\mathrm{pH}$, dan LCD. Perancangan alat berbasis mikrokontroler tidak dapat bekerja sesuai dengan yang diharapkan tanpa adanya perangkat lunak yang membuat mikrokontroler tersebut bekerja. Sistem perangkat yang digunakan dalam sistem ini menggunakan bahasa pemograman assembly untuk MCS-51. Pengoperasian alat dimulai dengan menguhubungkan catu daya $5 \mathrm{~V}$ untuk mengaktifkan perangkat- perangkat dalam alat ini mulai dari inframerah, photodioda, sensor $\mathrm{pH}$, mikrokontrolel serta tampilan pada LCD. Tampilan pada LCD akan menampilkan 
pengukuran kadar zat terlarut (TDS) dan derajat keasaman air atau $\mathrm{pH}$.

Tampilan fisik dari alat yang telah dirancang

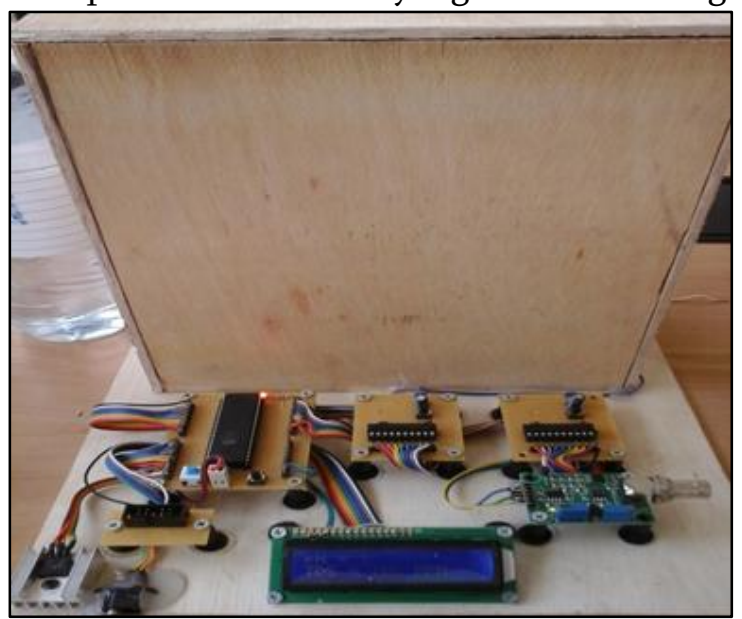

Pengujian TDS meter dan $\mathrm{pH}$ dengan alat yang dirancang



\section{Pengujian Sensor Kadar Zat Terlarut}

Kadar zat terlarut (TDS) menggambarkan sifat optik air yang ditentukan berdasarkan banyaknya cahaya yang diserap dan dipancarkan oleh bahan - bahan yang terdapat didalam air. Semakin tinggi nilai padatan tersuspensi, nilai kekeruhan juga akan semakin tinggi. Cahaya yang digunakan pada alat ini adalah cahaya LED dan Sensor yang digunakan dalam transmitter adalah fotodioda. Pada grafik pengujian $\mathrm{pH}$ dapat diketahui nilai regresi linier dari grafik sebesar y $=-21 \mathrm{x}-225$. Dimana $x$ adalah nilai ADC dan $y$ adalah kadar zat terlarut (TDS). Nilai koefisien determinasi pada regresi linear (r2) adalah 1 .



Grafik pengujian kalibrasi kadar zat terlarut

(TDS)

\section{Pengujian Sensor $\mathrm{pH}$}

$\mathrm{pH}$ adalah derajat keasaman yang digunakan untuk menyatakan tingkat keasaman atau kebasaan yang dimiliki oleh suatu larutan. Pengujian sensor $\mathrm{pH}$ menggunakan $\mathrm{pH}$ meter untuk referensi utama suspense standar dalam pengujian kalibrasi sensor ini. Pada grafik pengujian sensor $\mathrm{pH}$ dapat diketahui nilai regresi linier dari grafik sebesar $\mathrm{y}=-671 \mathrm{x}-78,67$. Dimana $x$ adalah nilai ADC dan $y$ adalah kadar zat terlarut (TDS). Nilai koefisien determinasi pada regresi linear $\left(r^{2}\right)$ adalah 0,971 .

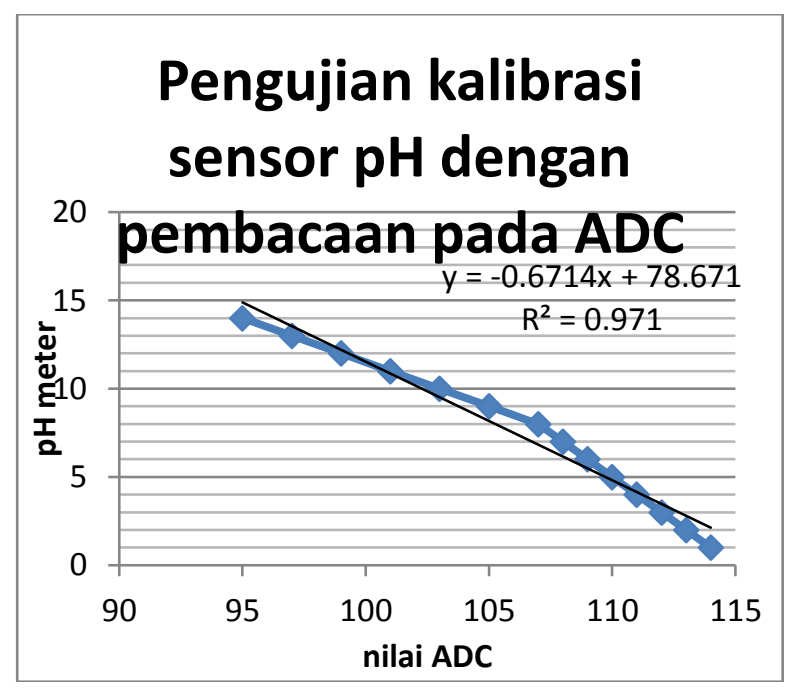

Grafik pengujian kalibrasi derajat keasaman $(\mathrm{pH})$ 
Pengujian Alat Pendeteksi Kelayakan Air Minum

Berdasarkan hasil pengujianalat pendeteksi kelayakan air minum yang dirancang dangan TDS Meter serta $\mathrm{pH}$ Meter yang di uji pada berbagai Air Minum Isi Ulang (AMIU) yang diproduksi depot air minum diperoleh data yang dibuat pada Tabel dibawah ini sebagai berikut :

Hasil pengujian kadar zat terlarut (TDS) alat yang dirancang dengan alat standar TDS Meter



\begin{tabular}{|c|c|c|c|c|}
\hline 10 & E & 8 & 7,6 & 0,4 \\
\hline 11 & B & 8 & 7,7 & 0,3 \\
\hline 12 & K & 8 & 8 & 0 \\
\hline 13 & J & 9 & 8 & 1 \\
\hline 14 & I & 9 & 8 & 1 \\
\hline 15 & L & 9 & 8 & 1 \\
\hline
\end{tabular}

Hasil pengujian derajat keasaman $(\mathrm{pH})$ alat yang dirancang dengan alat standar $\mathrm{pH}$ Meter

\section{Derajat Keasaman} (pH)

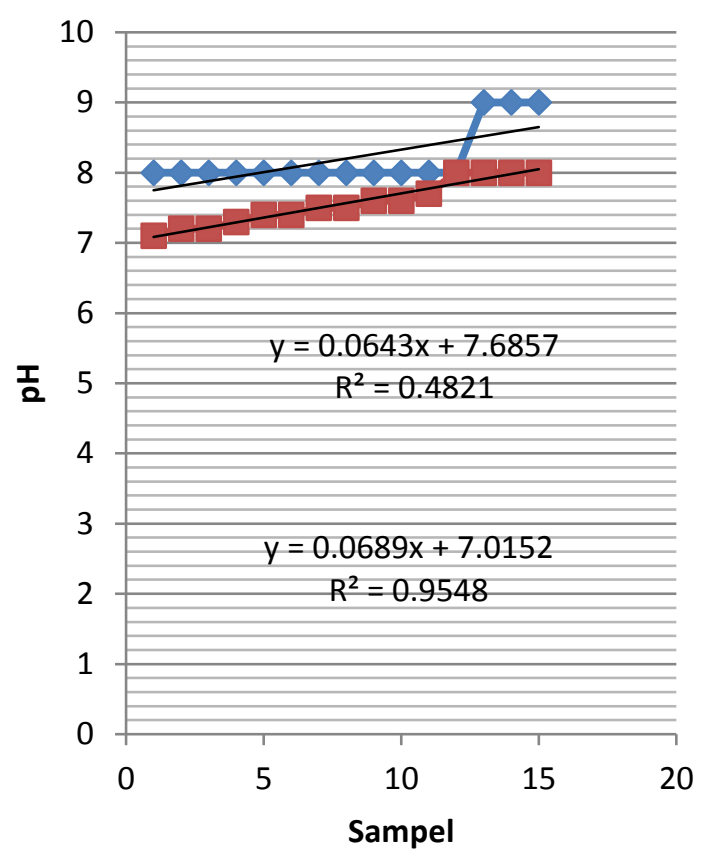

\begin{tabular}{|c|c|c|c|c|}
\hline \multicolumn{3}{|c|}{ =Alatyang dirancang } & \multicolumn{2}{|c|}{$=$ Alat standar (pHMeter) } \\
\hline no & sampel & $\begin{array}{l}\text { alat yang } \\
\text { dirancang }\end{array}$ & $\begin{array}{c}\text { alat } \\
\text { standar }\end{array}$ & $\begin{array}{c}\text { selisi } \\
\text { antara } \\
\text { alat yang } \\
\text { dirancang } \\
\text { dengan } \\
\text { alat } \\
\text { standar }\end{array}$ \\
\hline 1 & $\mathrm{~A}$ & 8 & 7,1 & 0,9 \\
\hline 2 & $\mathrm{C}$ & 8 & 7,2 & 0,8 \\
\hline 3 & G & 8 & 7,2 & 0,8 \\
\hline 4 & $\mathbf{M}$ & 8 & 7,3 & 0,7 \\
\hline 5 & $\mathrm{~F}$ & 8 & 7,4 & 0,6 \\
\hline 6 & $\mathrm{D}$ & 8 & 7,4 & 0,6 \\
\hline 7 & $\mathrm{O}$ & 8 & 7,5 & 0,5 \\
\hline 8 & $\mathbf{N}$ & 8 & 7,5 & 0,5 \\
\hline 9 & $\mathrm{H}$ & 8 & 7,6 & 0,4 \\
\hline 10 & $\mathrm{E}$ & 8 & 7,6 & 0,4 \\
\hline
\end{tabular}


Irpan Affandi dan Khairul Amdani, Rancang Bagun Alat Pendeteksi Kelayakan Air Minum Yang Diproduksi Depot Air Minum Isi Ulang (Amiu) Berbasis Mikrokontroler At89s51 Dan Lcd Menggunakan Inframerah Dan Photodioda Sebagai Indikator

\begin{tabular}{|c|c|c|c|c|}
\hline 11 & B & 8 & 7,7 & 0,3 \\
\hline 12 & K & 8 & 8 & 0 \\
\hline 13 & J & 9 & 8 & 1 \\
\hline 14 & I & 9 & 8 & 1 \\
\hline 15 & L & 9 & 8 & 1 \\
\hline
\end{tabular}

\section{Pembahasan}

Tegangan pada photodiode sangat tergantung pada intensitas cahaya yang mengenai permukaan photodiode. Cahaya yang sampai ke photodiode tergantung pada kekentalan larutan yang dilewati oleh cahaya yang dipancarkan oleh inframerah, semangkin kental larutan yang terdapat pada air maka intensitas cahaya yang mengenai photodiode semangkin kecildan sebaliknya. Intensitas cahaya yang diterima photodiode akan dikonversikan menjadi sinyal tegangan.

Berdasarkan data pengukuran menggunakan alat yang dirancang dengan alat yang standar selisih nilai koefisien yang diperoleh pada kadar zat terlarut (TDS) air minum isi ulang yang diproduksi depot air minum sebesar 0,002 sedangkan nilai koefisien derajat keasaman $(\mathrm{pH})$ air minum sebesar 0,474.

\section{Kesimpulan}

\section{KESIMPULAN DAN SARAN}

Berdasarkan hasil penelitian pendeteksi kelayakan air minum menggunakan inframerah, photodioda serta sensor $\mathrm{pH}$, disimpulkan:

1. Pembuatan rancangan alat pendeteksi kelayakan air minum berbasis mikrokontroler menggunakan inframerah dan photodioda sebagai indikator berkerja dengan baik sesuai bahasa yang disususn.

2. Penggunaan bahasa assembly untuk MCS-51 yang telah disusun sehingga detector dapat menjalankan fungsi sesuai dengan kebutuhan dalam penelitian.

3. Penggunaan indikator inframerah, photodioda diperoleh selisih nilai koefisien yang diperoleh pada kadar zat terlarut (TDS) air minum isi ulang yang diproduksi depot air minum sebesar 0,002 .

4. Pengguanaan sensor $\mathrm{pH}$ untuk mengukur derajat keasman air minum nilai koefisien derajat keasaman $(\mathrm{pH})$ air minum sebesar 0,474 .

\section{Saran}

Berdasarkan hasil penelitian dan pengolahan data alat pendeteksi kelayakan Air Minum Isi Ulang (AMIU) menggunakan inframerah dan photodioda sebagai indkator pada pendeteksian kadar zat terlarut serta sensor $\mathrm{pH}$ pada menentukan derajat keadaman air minum, dengan itu peneliti memberikan masukkan untuk penelitian seterusnya :

1. Perancangan pendeteksi kelayakan air minum dengan berbasis mikrokontroler yang lebih tinnggi bitnya seperti mikrokontroler AVR.

\section{DAFTAR PUSTAKA}

Aryanto, V., Rohmad, M., dan Puspita, E., (2010), Sistem Pendeteksi Kelayakan Air Minum Dalam Kemasan (AMDK) sebagai Solusi Alternatif BPOM Berbasis Mikrokntroler. Institut Teknologi Sepuluh November.

Asfawi, S., (2004), Analisis Faktor Yang Berpengaru Dengan Kualitas Bakteriologis Air Minum Isi Ulang Pada Tingkat Produsen Di Kota Semarang. Tesis, Universitas Diponegoro. Semarang.

Ginting, J. F., (2013), Perancangan alat ukur kekeruhan air menggunakan Light Depertemen Resistor Berbasis Mikrokontroler Atmega 8535, E-jurnal teknik elektro dan computer.

Nazula,N,.I., dan Endarko., (2013), Perancang dan Pembuatan Alat Ukur Kekeruhan Air Berbasis Mikrokontroler ATMega 8535, Jurnal Sains Dan Seni Pomits, Vol 2 No.1:1-5.

Menteri Kesehatan Republik Indonesia, (2002). Syarat-syarat dan pengawasan kualitas air minum, Nomor 907/MENKES/SK/VII/2002.

Menteri Kesehatan Republik Indonesia, (2010). Syarat-syarat dan pengawasan kualitas air minum, NO 492/MENKES/PER/IV/2010. 